\title{
Land-Cover Change in the Central Irregular Plains,
} 1973-2000

Open-File Report 2009-1159

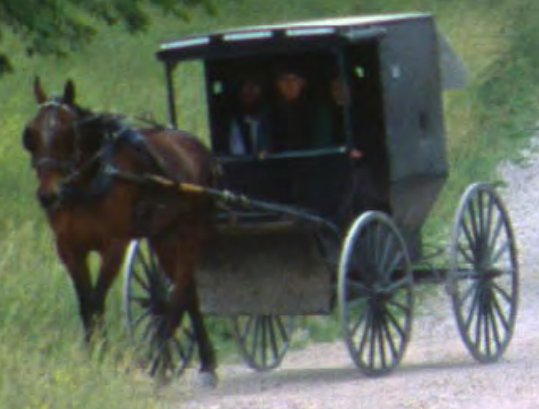

U.S. Department of the Interior U.S. Geological Survey 
Cover photograph. Horse drawn carriage in the northwest region of the Central Irregular Plains (U.S. Geological Survey, 2006). 


\section{Land-Cover Change in the Central Irregular Plains, 1973-2000}

By Krista A. Karstensen

Open-File Report 2009-1159 


\title{
U.S. Department of the Interior \\ KEN SALAZAR, Secretary
}

\author{
U.S. Geological Survey \\ Suzette M. Kimball, Acting Director
}

U.S. Geological Survey, Reston, Virginia: 2009

For more information on the USGS - the Federal source for science about the Earth, its natural and living resources, natural hazards, and the environment, visit http://www.usgs.gov or call 1-888-ASK-USGS

For an overview of USGS information products, including maps, imagery, and publications, visit http://www.usgs.gov/pubprod

To order this and other USGS information products, visit http://store.usgs.gov

Any use of trade, product, or firm names is for descriptive purposes only and does not imply endorsement by the U.S. Government.

Although this report is in the public domain, permission must be secured from the individual copyright owners to reproduce any copyrighted materials contained within this report.

Suggested citation:

Karstensen, K.A., 2009, Land-Cover Change in the Central Irregular Plains, 1973-2000: U.S. Geological Survey OpenFile Report 2009-1159, 8 p. 


\section{Contents}

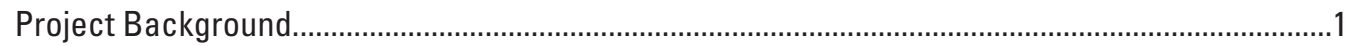

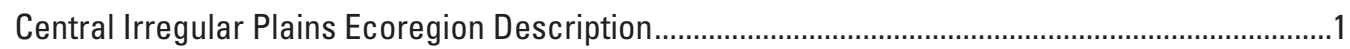

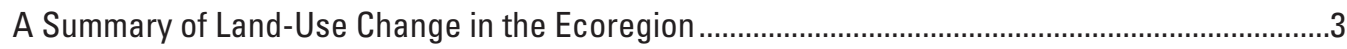

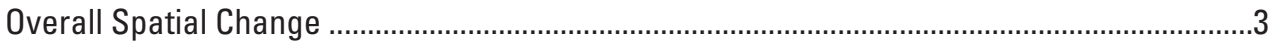

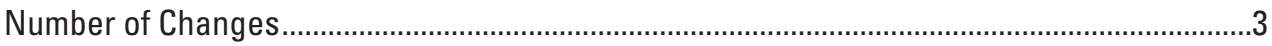

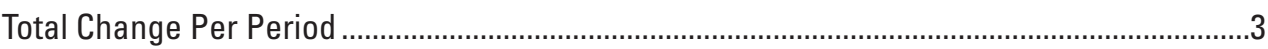

Land-Cover Composition and Net Change .........................................................................

Most Common Land-Cover Conversions ...............................................................................

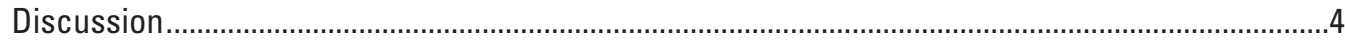

Factors Affecting Land-Cover Change in the Ecoregion.......................................................

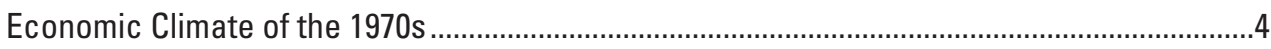

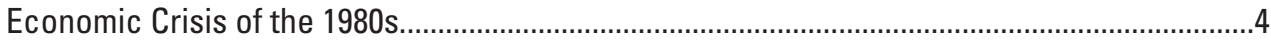

No-Till Conservation Tillage .........................................................................................

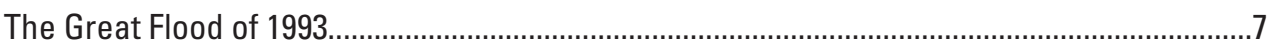

The Conservation Reserve Program ......................................................................................

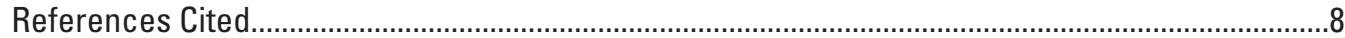

\section{Figures}

1. Map showing the Central Irregular Plains ………..........................................................2

2-4. Photographs showing-

2. Wheat field near Jasper, Missouri ..............................................................................

3. No-till farming near Hamilton, Missouri ..........................................................................

4. Conservation Reserve Program land near Graysville, Missouri ....................................7

\section{Tables}

1. Percentage of the Central Irregular Plains that experienced change and associated error

2. Raw estimates of percent change in the Central Irregular Plains computed for each of the four time periods and associated error at an 85-percent confidence level.

3. Estimated area for each land-cover class in the Central Irregular Plains between 1973 and 2000

4. Leading land-cover conversions in the Central Irregular Plains during each of four time periods 


\section{Conversion Factors}

\begin{tabular}{lcl}
\hline \multicolumn{1}{c}{ Multiply } & By & \multicolumn{1}{c}{ To obtain } \\
\hline centimeter $(\mathrm{cm})$ & Length & \\
kilometer $(\mathrm{km})$ & 0.3937 & inch (in.) \\
\hline \multicolumn{2}{c}{0.6214} & mile (mi) \\
\hline square kilometer $\left(\mathrm{km}^{2}\right)$ & Area & \\
\hline
\end{tabular}

Horizontal coordinate information is referenced to the North American Datum of 1983 (NAD 83). 


\title{
Land-Cover Change in the Central Irregular Plains, 1973-2000
}

\author{
By Krista A. Karstensen
}

\section{Project Background}

Spearheaded by the Geographic Analysis and Monitoring Program of the U.S. Geological Survey (USGS) in collaboration with the U.S. Environmental Protection Agency (EPA) and the National Aeronautics and Space Administration (NASA), the Land Cover Trends is a research project focused on understanding the rates, trends, causes, and consequences of contemporary United States land-use and land-cover change. Using the EPA Level III ecoregions as the geographic framework, scientists process geospatial data collected between 1973 and 2000 to characterize ecosystem responses to land-use changes. The 27 -year study period was divided into five temporal periods: 1973-1980, 1980-1986, 1986-1992, 1992-2000 and 1973-2000. General land-cover classes for these periods were interpreted from Landsat Multispectral Scanner, Thematic Mapper, and Enhanced Thematic Mapper Plus imagery to categorize land-cover change and evaluate using a modified Anderson Land Use Land Cover Classification System for image interpretation.

The rates of land-cover change are estimated using a stratified, random sampling of 10-kilometer $(\mathrm{km})$ by $10-\mathrm{km}$ blocks allocated within each ecoregion. For each sample block, satellite images are used to interpret land-cover change. Additionally, historical aerial photographs from similar timeframes and other ancillary data such as census statistics and published literature are used. The sample block data are then incorporated into statistical analyses to generate an overall change matrix for the ecoregion. These change statistics are applicable for different levels of scale, including total change for the individual sample blocks and change estimates for the entire ecoregion. The results illustrate that there is no single profile of land-cover change but instead point to geographic variability that results from land uses within ecoregions continuously adapting to various factors including environmental, technological, and socioeconomic.

\section{Central Irregular Plains Ecoregion Description}

The Central Irregular Plains ecoregion, as defined by Omernik (1987), encompasses 122,589 square kilometers $\left(\mathrm{km}^{2}\right)$ across southern Iowa, northern and central Missouri and fractions of eastern Kansas and northeastern Oklahoma (fig. 1). The ecoregion includes the Chariton, Des Moines, Grand, Missouri, and Thompson Rivers and their tributaries.

The Central Irregular Plains tends to be topographically more irregular than the Western Corn Belt Plains to the north but is less irregular and less forested than the ecoregions to the south and east. The topography of the northern sections of the Central Irregular Plains found in northern Missouri and southern Iowa ranges from flat to moderately hilly. This portion of the ecoregion includes natural wetlands along the Grand River. The soils in the ecoregion vary from north to south in that glacial tills form the parent material for most of the soil in Iowa and the northern half of Missouri while the southern portion of the ecoregion was not glaciated (Chapman and others, 2002). Additionally, loess deposits generally increase near the Missouri River (Chapman and others, 2002). The topographic features of the southwestern sections of the ecoregion, in west central Missouri, western Kansas, and northern Oklahoma generally are smoother than the northern till plains (Chapman, and others, 2002). This nonglaciated area is relatively flat and can be distinguished by its claypan soils (Chapman and others, 2002).

The Central Irregular Plains has a variety of land-use types. The gently rolling topography and generally fertile soils of this ecoregion support a variety of agricultural practices, like the contour farming common in Iowa and northern Missouri (Chapman and others, 2002). Agricultural land stretches across the entire boundary of the Central Irregular Plains and is composed of fields of corn, soybeans, and wheat, as well as cattle. Loess deposits near the Missouri River have helped to create inherently fertile soils that provide an ideal environment for crop production (U.S. Department of Agriculture, 2009a) 


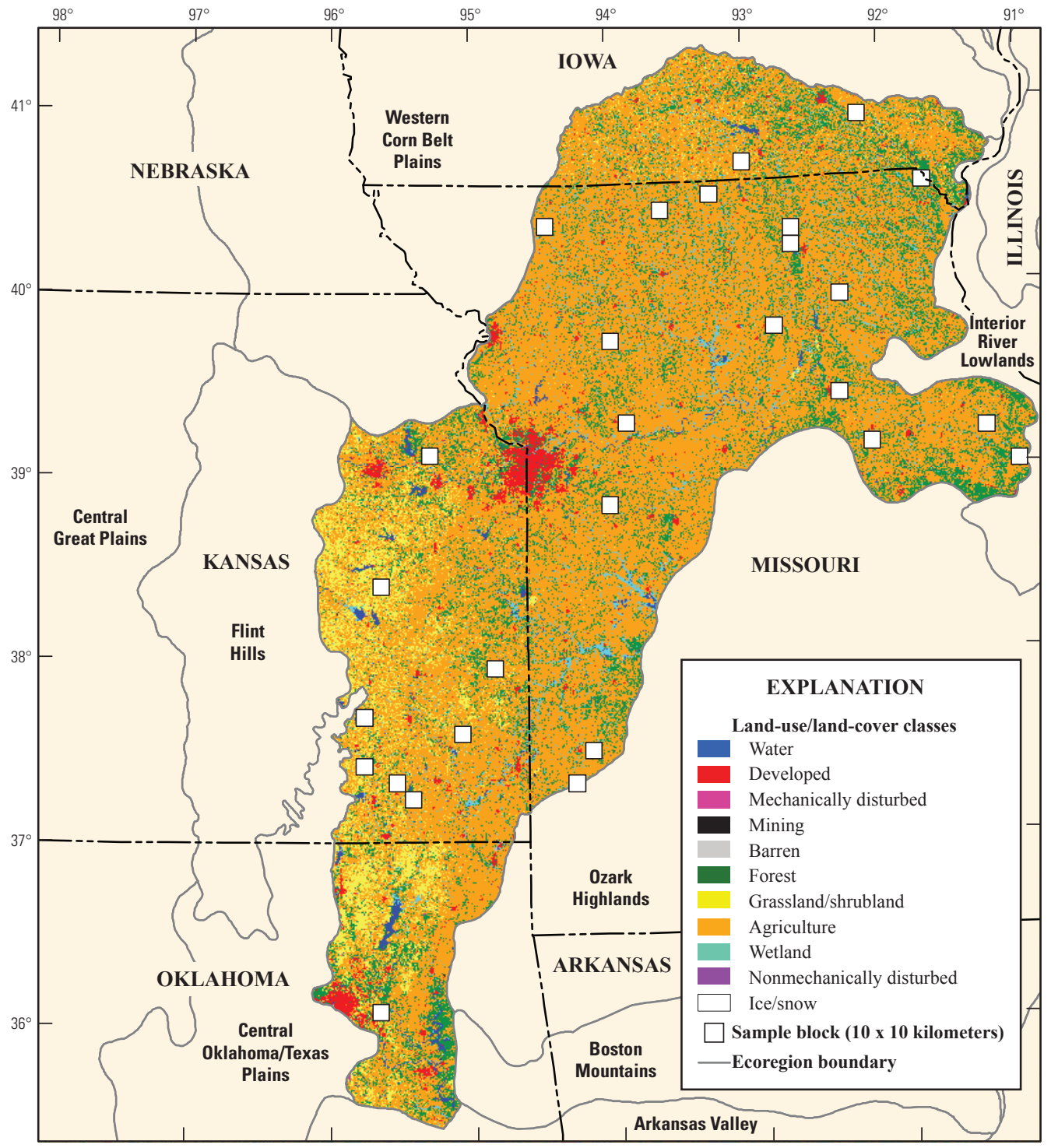

Base from Environmental Systems Research Institute digital data, 1983 Albers Projection

North American Datum of 1983 (NAD 83)
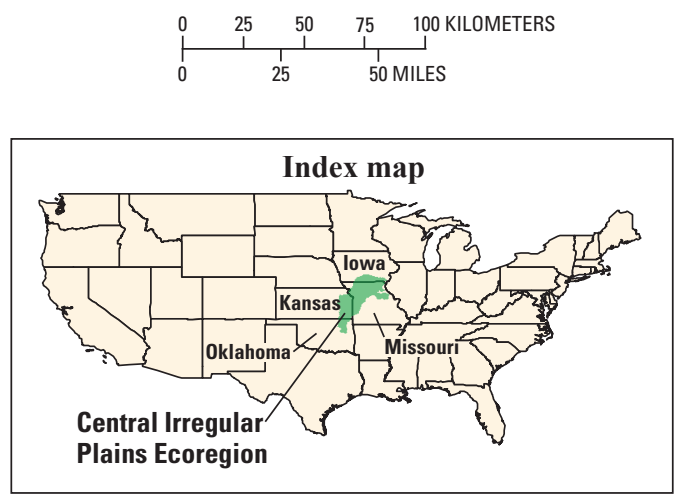

Figure 1. The Central Irregular Plains. 
(fig. 2). According to the U.S. Department of Agriculture's National Agricultural Statistics Service (NASS), a majority of the Iowa counties in this ecoregion have at least 50 percent of their land in farms as cropland. To the southwest, the primary crops during the study period in the Kansas counties of the ecoregion were wheat, corn, and sorghum while the counties in Oklahoma harvested mostly wheat and soybeans (U.S. Department of Agriculture Kansas National Agricultural Statistics Service, 2009c and U.S. Department of Agriculture Oklahoma National Agricultural Statistics Service, 2009e).

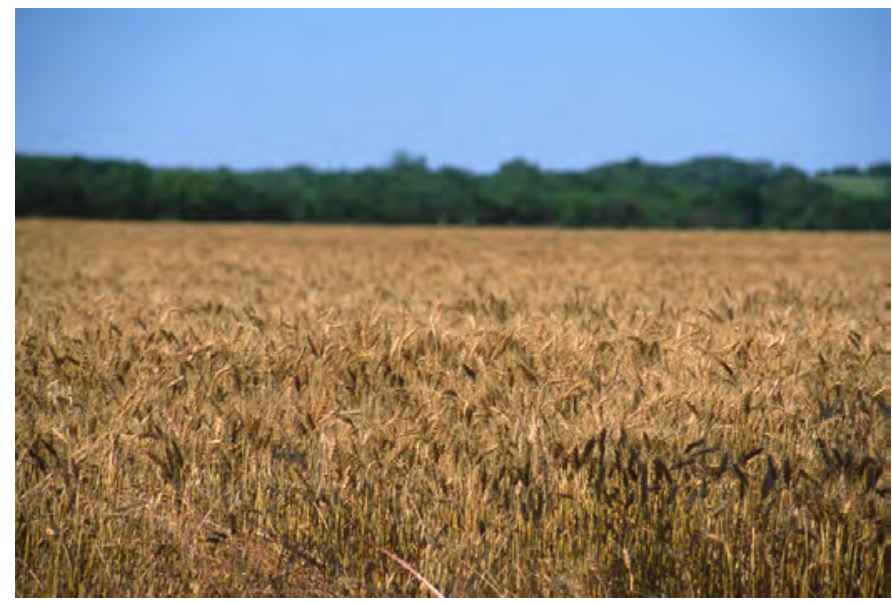

Figure 2. Wheat field near Jasper, Missouri (U.S. Geological Survey, 2006).

\section{A Summary of Land-Use Change in the Ecoregion}

\section{Overall Spatial Change}

From 1973 to $2000,7.2$ percent (+/- 2.0 percent) of the Central Irregular Plains ecoregion underwent land-cover change (table 1). When compared to the statistics calculated for the other ecoregions in the Great Plains, the overall spatial change in the Central Irregular Plains was moderate. Results also indicate that the Central Irregular Plains show a greater amount of change than the neighboring ecoregions of the Great Plains.

\section{Number of Changes}

An estimated 6.5 percent of land cover in the ecoregion underwent change once. The percentage of the ecoregion that changed more than once during the 30-year study period was low; 0.7 percent of the area changed twice, 0.1 percent changed three times. According to the statistics, the percent of the area that changed twice in this ecoregion is moderately consistent with neighboring ecoregions.

\section{Total Change Per Period}

The total amount of change was relatively low during the study period. The total change during the 1973 to 1980 time period was 1.8 percent (+/- 0.6 percent). During the 19861992 and the 1992-2000 time periods, the total change slightly increased to 2.0 percent $(+/-0.6$ percent) and 2.2 percent $(+/-$ 0.8 percent) respectively. (table 2 ). Overall, these changes are moderately higher than values for the neighboring ecoregions. All of the change estimates have an associated margin of error of less than $+/-0.9$ percent. The margin of error varied directly with the percent change in that it decreased with the lower amount of change from 1986 to 1992 and increased slightly between 1992 and 2000.

\section{Land-Cover Composition and Net Change}

Agriculture is the principal land cover in the Central Irregular Plains. Though it experienced a slight decline to grassland/shrubland, agriculture covered 59.9 percent $(+/-$ 4.8 percent) of the ecoregion in 2000 (table 3 ). Forest was the second highest land-cover type covering 20.4 percent of the ecoregion in 1973 and 20 percent in 2000 (table 3). The forested woodlands of the Central Irregular Plains, including oak-hickory, are primarily concentrated in the eastern portion of the ecoregion. Grassland/shrubland, the third most extensive land-cover type, had a steady gain from 13.5 percent in 1973 to 15.9 percent in 2000 (table 3).

Table 1. Percentage of the Central Irregular Plains that experienced spatial change and associated error.

[+, plus; -, minus; \%, percent]

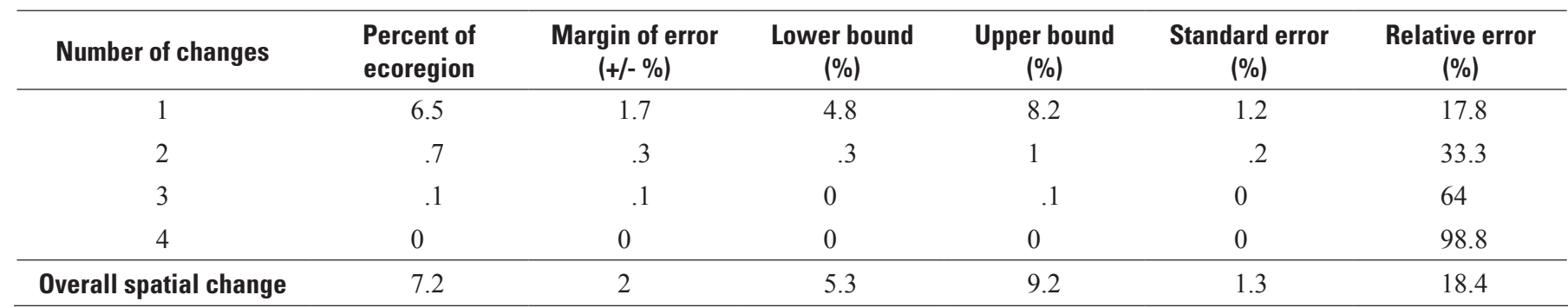


Table 2. Raw estimates of percent change in the Central Irregular Plains computed for each of the four time periods and associated error at an 85-percent confidence level.

$\left[\%\right.$, percent; +, plus; -, minus; $\mathrm{km}^{2}$, square kilometers $]$

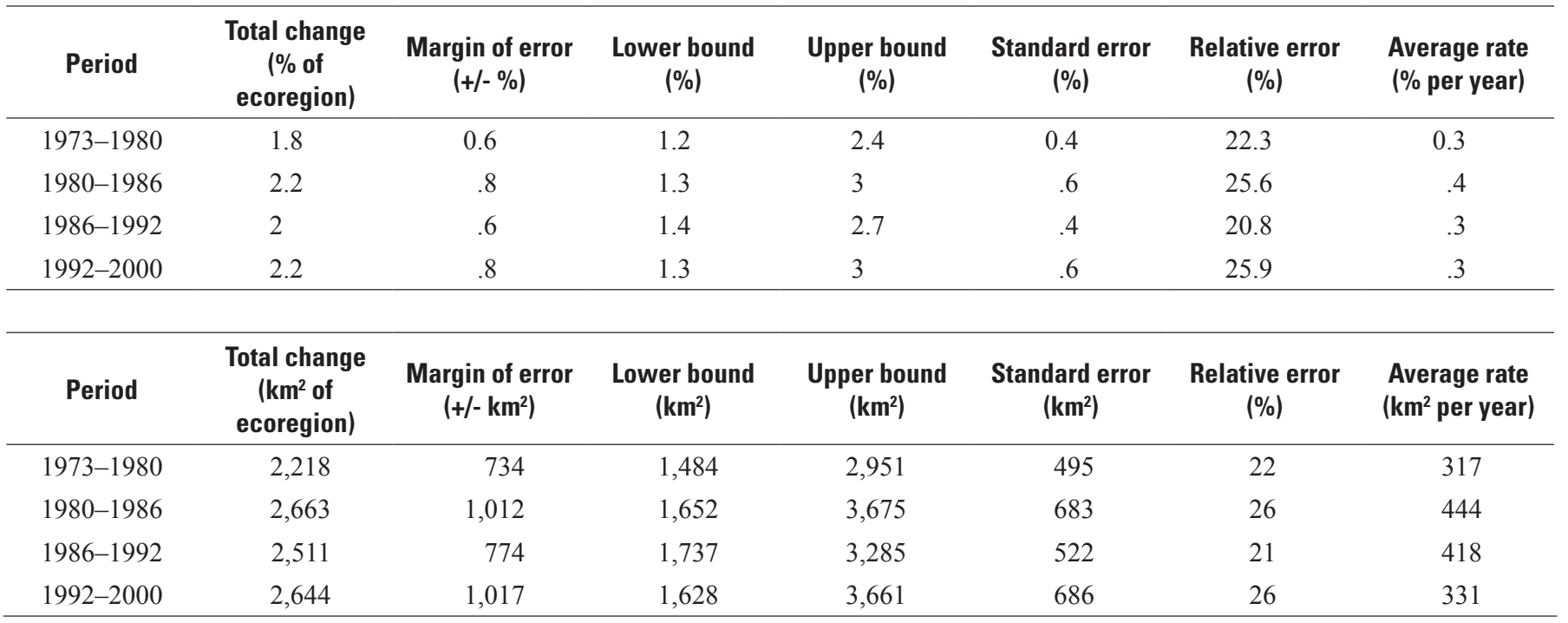

\section{Most Common Land-Cover Conversions}

The five leading land-cover conversions from 1973 to 2000 were: (1) agriculture to grassland/shrubland, (2) grassland/shrubland to agriculture, (3) agriculture to developed, (4) forest to agriculture, and (5) grassland/shrubland to forest (table 4).

Overall, the most common type of conversion during each study period was the conversion from agriculture to grassland/shrubland. Between 1973 and 2000, 5,362 km² were converted from agriculture to grassland/shrubland (table 4). However, this conversion did not result in a large net increase in grassland/shrubland because during the same time, the second most common conversion was grassland/shrubland being converted to agricultural land $\left(2,128 \mathrm{~km}^{2}\right)$.

\section{Discussion}

In 2000, agricultural land accounted for the highest amount of area in the ecoregion $\left(73,466 \mathrm{~km}^{2}\right)$ despite a net decrease of 3.02 percent. Economics play an important role in the land-use story of the Central Irregular Plains.

\section{Factors Affecting Land-Cover Change in the Ecoregion}

The major factors affecting conversion of agricultural land to grassland/shrubland land during the study period were:

- the economic crisis of the 1980's;

- the agroeconomics related to advances in conservation tillage (no-till);
- the socioeconomic repercussions associated with the Great Flood of 1993; and

- the Conservation Reserve Program (CRP).

\section{Economic Climate of the 1970s}

The economic climate of the 1970s encouraged farmers to expand production in an effort to benefit from improved export opportunities, strong commodity prices, farm income, and farmland values. While abundant credit from various sources helped finance the expansion, high rates of inflation and low real-estate interest rates further encouraged investment in farmland. During this time, a considerable number of farmers took on heavy debt loads and became vulnerable to sudden shifts in economic forces (Stam and Dixon, 2004).

\section{Economic Crisis of the 1980s}

During the economic crisis of the early 1980s, those economic shifts were felt when economic conditions reversed and export markets contracted and input prices and interest rates rose (Stam and Dixon, 2004). Monetary policies designed to reduce inflation prompted interest rates to rise to unprecedented levels in the early 1980s. The financial stress became more severe when declines in farm commodity prices, income, and land values (the largest asset used to secure debt) made it difficult for some farmers to service their debts (Stam and Dixon, 2004). While several factors came together to create the crisis, the massive increase in farmland prices in the late 1970s, followed by the sharp decline in land prices between 1981 and 1992, significantly contributed to the adverse effects on farmers and their lenders (Cofer and others, 2009) and may 


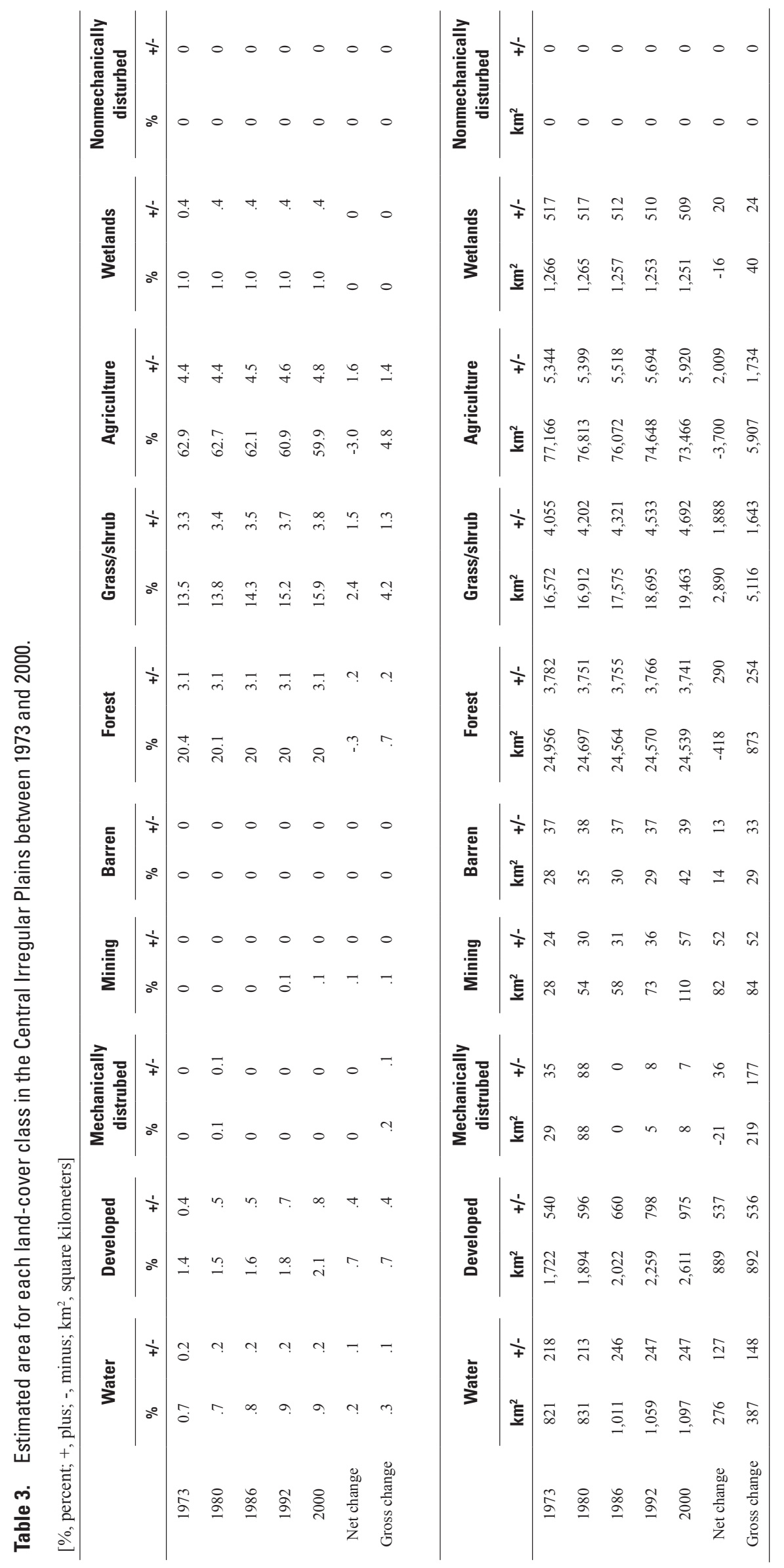


Table 4. Leading land-cover conversions in the Central Irregular Plains during each of four time periods.

$\left[\mathrm{km}^{2}\right.$, square kilometers; +, plus; -, minus $]$

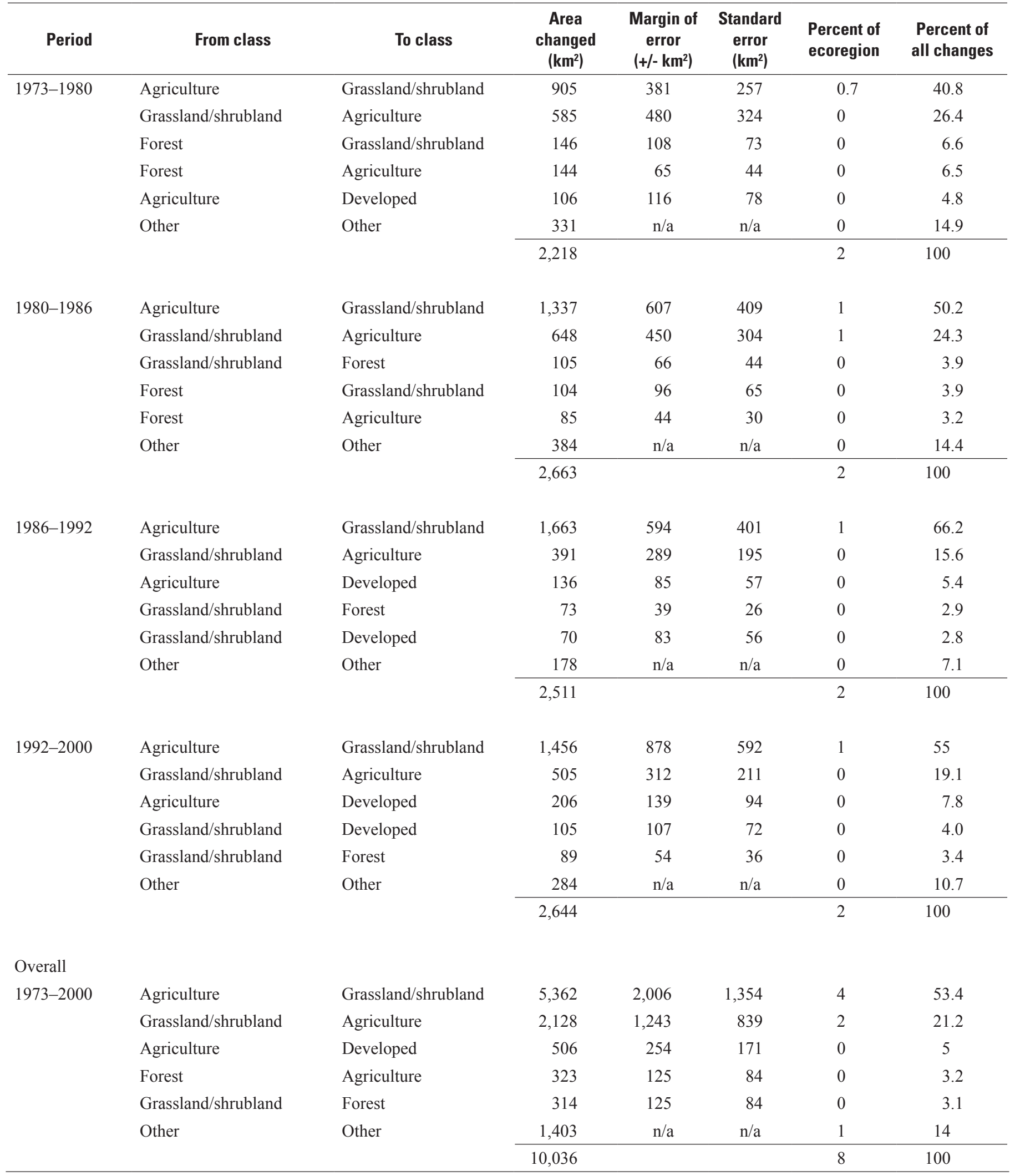


have had an affect in the amount of agricultural land in the Central Irregular Plains.

A direct example of the effects of this crisis was found in Appanoose County, Iowa. The banking crisis of the early 1980s was the cause of many land-use changes in southern Iowa (D. Clarke, U.S. Department of Agriculture, written commun., 2009). The financial institutions needed money back from farmers because of the low crop yields (D. Clarke, U.S. Department of Agriculture, written commun., 2009). Overall, the collapse of the farm banks in the 1980s inflicted particular economic hardship on small family-operated farms as a number of farm banks failed causing many to foreclose on their farms.

\section{No-Till Conservation Tillage}

The second economic factor affecting land-use change in the Central Irregular Plains is conservation tillage, specifically no-till. No-till conservation tillage was not only popular but encouraged in many parts of the ecoregion in the 1980s and continues to be widely practiced. No-till is a practice where the soil is left virtually undisturbed from harvest to planting and has increased specifically in southern Iowa and eastern Kansas in recent years (D. Clarke, U.S. Department of Agriculture, written commun., 2009; M. Glissman, U.S. Department of Agriculture, written commun., 2009). The overall rate of increase in the use of conservation tillage of non-highly erodible land has been similar to that on highly erodible land, indicating that all producers are motivated by the potential of conservation tillage systems to reduce costs, improve efficiency, and increase soil productivity (U.S. Department of Agriculture Economic Research Service, 1997). However, the use of conservation tillage has leveled off in several regions since 1993 due in part to the unusual weather patterns - primarily heavy rainfall and cool planting conditions, which create unfavorable planting conditions for conservation tillage (U.S. Department of Agriculture Economic Research Service, 1997). It is important to note that more than 50 percent of the scenes used to classify these data were collected from spring and late fall months, which may explain that while the land in no-till has an agricultural land use, it may spectrally appear as grassland/shrubland (fig. 3).

\section{The Great Flood of 1993}

The devastation of cropland that was associated with the Great Flood of 1993 had an affect on land use in the Central Irregular Plains. Specifically, greater than 61 centimeters $(\mathrm{cm})$ of rain fell on central and northeastern Kansas, northern and central Missouri, most of Iowa, southern Minnesota, and southeastern Nebraska, and as much as $97 \mathrm{~cm}$ fell in east-central Iowa (Johnson and others, 2004). These amounts were approximately 2003 to 50 percent greater than normal (Johnson and others, 2004). From April 1 to August 31, precipitation amounts approached $122 \mathrm{~cm}$ in east-central Iowa, easily sur-

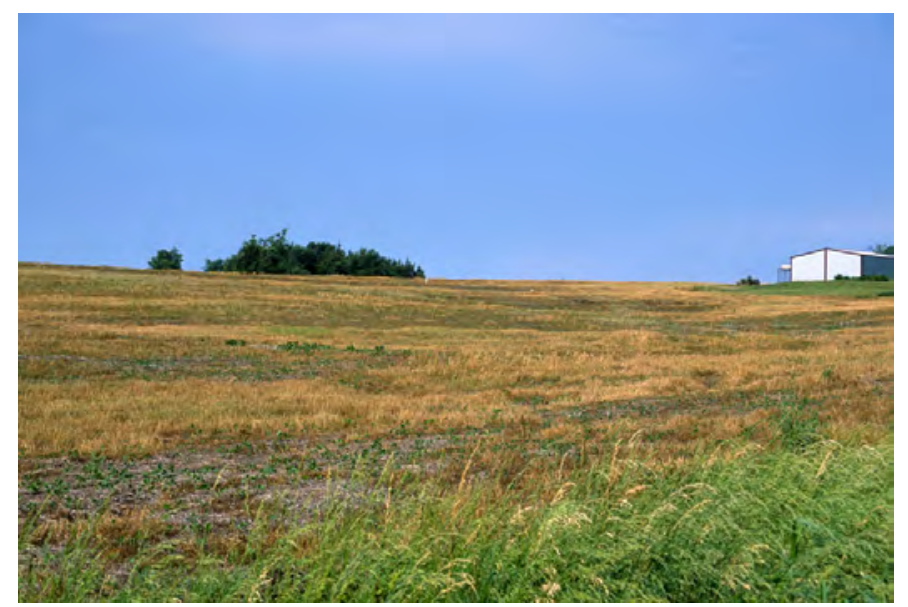

Figure 3. No-till farming near Hamilton, Missouri (U.S. Geological Survey, 2006).

passing the area's normal annual precipitation of 76 to $91 \mathrm{~cm}$ (Johnson and others, 2004). A substantial amount of cropland was lost, which had a particular downward effect on soybean and corn yields. While the floodwaters did not have a substantial effect on the entire ecoregion, the extent of the damage on agricultural resources was essential to understanding how climatic affects on land use may affect the land change.

\section{The Conservation Reserve Program}

The U.S. Department of Agriculture NASS CRP annual cumulative enrollment statistics show that overall, acres enrolled in the CRP in the ecoregion declined slightly in the later portion of the study period (fig. 4). While that may have had a significant affect on the land-change conversion from agriculture to grassland/shrubland, other factors such as economics and climate also should be considered.

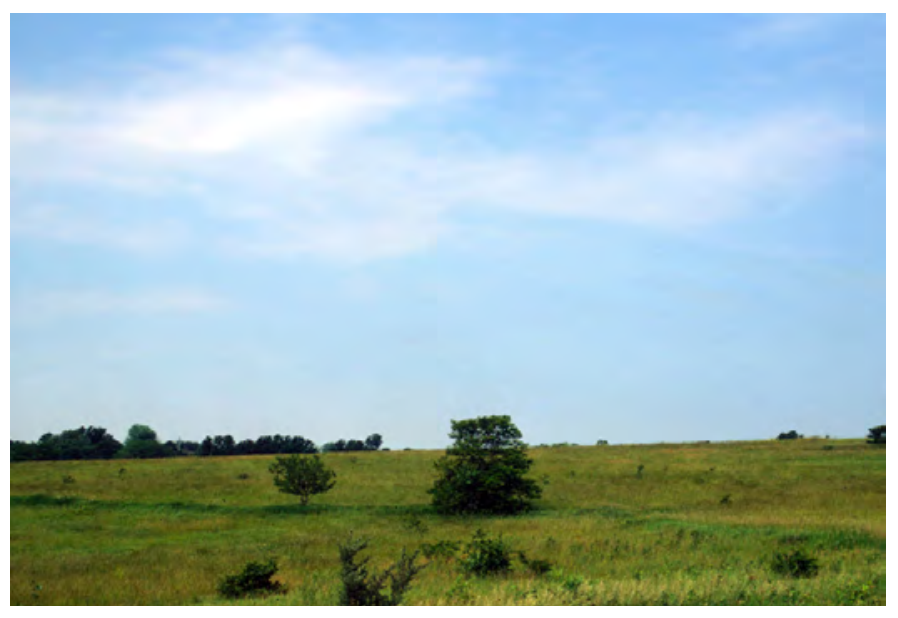

Figure 4. Conservation Reserve Program land near Graysville, Missouri (U.S. Geological Survey, 2006). 


\section{References Cited}

Chapman, S.S., Omernik, J.M., Griffith, G.E., Schroeder, W.A., Nigh, T.A., and Wilton, T.F., 2002, Ecoregions of Iowa and Missouri: Reston, Virginia, U.S. Geological Survey, accessed on September 1, 2008, at URL ftp://ftp.epa. gov/wed/ecoregions/mo_ia/moia_front.pdf

Cofer, R.D., Walser, J.W., and Osborne, T.D., 2009, Do record farmland prices portend another steep downturn for agriculture and farm banks: Washington, D.C., Federal Deposit Insurance Corporation, accessed on March 18, 2009, at URL http://www.fdic.gov/bank/analytical/quarterly/2008_ vol2_4lfarmland.html

Johnson, G.P., Holmes, R.R., and Waite, L.A., 2004, The great flood of 1993 on the Upper Mississippi River-10 years later: U.S. Geological Survey Fact Sheet 2004-3024, 6 p.

Omernik, J.M., 1987, Ecoregions of the conterminous U.S.: Annals of the Association of American Geographers, v. 77, no. 1 , p. 118-125.

Stam, J.M., and Dixon, B.L., 2004, Farmer bankruptcies and farm exits in the United States, 1899-2002: Washington, D.C., Economic Research Service, U.S. Department of Agriculture, Agriculture Bulletin Number 788, accessed on March 18, 2009, at URL http://www.ers.usda.gov/ publications/aib788/aib788.pdf

U.S. Department of Agriculture, Farm Service Agency, 2009a, Conservation Programs: CRP contract and summary statistics: Washington, D.C., U.S. Department of Agriculture, accessed on March 11, 2009, at URL http://www. fsa.usda. gov/FSA/webapp? area $=$ home\&subject $=$ copr\&topic $=$ crp-st
U.S. Department of Agriculture, National Agricultural Statistics Service, 2009b, Iowa statistics: Washington, D.C., U.S. Department of Agriculture, accessed on March 11, 2009, at URL http://www.nass.usda.gov/Statistics_by_State/Iowa/ index.asp

U.S. Department of Agriculture, National Agricultural Statistics Service, 2009c, Kansas statistics: Washington, D.C., U.S. Department of Agriculture, accessed on March 11, 2009, at URL http://www.nass.usda.gov/Statistics_by_State/ Kansas/index.asp

U.S. Department of Agriculture, National Agricultural Statistics Service, 2009d, Missouri statistics: Washington, D.C., U.S. Department of Agriculture, accessed on March 11, 2009, at URL http://www.nass.usda.gov/Statistics_by_State/ Missouri/index.asp

U.S. Department of Agriculture, National Agricultural Statistics Service, 2009e, Oklahoma statistics: Washington, D.C., U.S. Department of Agriculture, accessed on March 11, 2009, at URL http://www.nass.usda.gov/Statistics_by_State/ Oklahoma/index.asp

U.S. Department of Agriculture, Economic Research Service, Natural Resources and Environment Division, 1997, Agricultural Resources and Environmental Indicators, 1996-97: Agricultural Handbook No. 712. Washington, DC.

U.S. Geological Survey, 2001, Multi-Resolution Land Characteristics Consortium: National Land Cover Database (NLCD 2001) Multi-zone Download Site accessed on June 4, 2009, at URL http://www.mrlc.gov/nlcd_multizone_map. phP
Publishing support provided by:

Rolla Publishing Service Center

For more information concerning this publication, contact:

Director

U.S. Geological Survey

Mid-Continent Geographic Science Center

1400 Independence Road

Rolla, M0 65401

(573) 308-3550

Or visit the Mid-Continent Geographic Science Center website at: http://mcgsc.usgs.gov/ 

